\title{
DEBATINDLAEG
}

\section{Styringen af de offentligt ansatte har taget overhånd}

Socialrådgivere er blevet administratorer, pædagoger 'opbevarer' børn, mens sygeplejersker må have løbesko på for at nå alle patienter. Er det sådan, vi ønsker at bruge de offentligt ansattes faglige kompetencer - eller kan vi finde på klogere løsninger til at lette presset på det offentlige arbejdsmarked?

\section{Af Mads Bilstrup}

Da jeg i marts måned i år læste resultatet af en ny, uvildig undersøgelse af danske lønmodtageres arbejdsmiljø fra Det Nationale Forskningscenter for Arbejdsmiljø, blev jeg både vred og ked af det. For den viste, at socialrådgiverne er den gruppe på det danske arbejdsmarked, som er mest stresset og mindst kan overskue deres arbejde.

Resultatet bekræftes af en undersøgelse, Dansk Socialrådgiverforening selv gennemførte i efteråret. Den slog fast, at hver tredje socialrådgiver føler sig stresset.

Jeg bliver vred og ked af det, fordi det i min optik aldrig har været meningen, at det skal have de konsekvenser at gå på arbejde. Og fordi det er sørgeligt - både for den enkelte socialrådgiver, kollegerne og ikke mindst for de borgere, som har brug for, at der både er tid og overskud til at hjælpe dem i en ofte svær livssituation.

Men jeg bliver også vred, fordi det både opleves som uansvarligt og kynisk at pålægge ansatte så mange opgaver og krav, at de ikke har en jordisk chance for at leve op til dem uden at gå på kompromis med deres faglighed eller med risiko for at gå hjem med en stresssygemelding.

\section{Krav og ressourcer er ude af balance}

De nuværende vilkår udfordrer både faglighed, arbejdsglæde og livskvalitet hos de ansatte og de borgere, de er ansat til at arbejde med. Og det kan vel ikke være meningen med et offentligt velfærdssystem, hvis medarbejdere er her for at gøre en forskel for mennesker, som har brug for både den faglige og personlige støtte og indsats, som fx en socialrådgiver kan levere. Det gælder uanset, om vi taler om udsatte familier og deres børn, mennesker med handicap eller borgere, som skal hjælpes tilbage i job eller uddannelse.

Så når vi taler om, at det offentlige arbejdsmarked er under pres, kan jeg kun til- 
slutte mig diagnosen. Når forholdet mellem tilgængelige ressourcer og stillede krav, både hos den enkelte og på samfundsniveau, er så langt fra hinanden, er der noget galt.

Hvad er der så galt? Faktisk en form for catch 22, som jeg ser det. Når politikerne med den ene hånd forlanger output af de penge, de sender ud i velfærdssystemet i form af dokumenteret effekt og resultater, og med den anden hånd sender tsunamier af ny lovgivning og reformer afsted, hvis procesog dokumentationskrav kun vokser, bliver det umuligt at levere det ønskede output. Og dermed umuligt at dokumentere, fordi al tiden går med at ... dokumentere.

Og når der så blusser en enkeltsag op i medierne om en borger, som ikke har fået den hjælp, vedkommende lovmæssigt har krav på, reagerer politikerne nærmest pr. automatik med at sende endnu flere proces- og dokumentationskrav afsted efter de offentligt ansatte - i et håb om, at støtten næste gang så bliver bedre.

Det gør den ikke. Tværtimod. Og dette styringsregime har taget overhånd.

\section{Bruger 48 minutter i timen på administration}

Tag fx socialrådgiverne på beskæftigelsesområdet. Deres fornemste opgave - kerneopgave om man vil - er at hjælpe ledige borgere i job eller uddannelse, gør dem selvforsørgende og uafhængige af det offentlige velfærdssystem.

Men socialrådgiverne i jobcentersystemet bruger 80 procent af deres tid på at administrere. Dvs. fodre systemer med informationer, så man kan følge output af deres arbejde i form af statistikker osv., så politikere og andre stakeholdere i sidste ende kan se, om der er valuta for pengene.

Men humlen er jo, at jo mere tid, socialrådgiveren bruger på at administrere, rapportere og dokumenter, desto mindre tid har hun til at hjælpe borgeren i job eller uddannelse. Logisk og indlysende nok, tænker man, men den logik er mærkeligt nok ikke - trods alverdens afbureaukratiserings- og moderniseringsøvelser fra Christiansborgs side - slået igennem i praksis endnu.

\section{Pædagogerne 'opbevarer' børn}

Men er det ikke rimeligt, at vi holder øje med, om de offentligt ansatte skaber værdi for pengene, fx i form af job eller uddannelse for de ledige? Jo, bestemt. Som socialrådgivere vil vi også gerne lave administrativt arbejde. Men jeg gentager: Det har taget overhånd.

Det gælder jo ikke kun medlemmerne af den fagforening, jeg tilfældigvis står i spidsen for. Vi hører også om, hvordan pædagoger ikke længere passer børnene. De opbevarer dem. For der er så mange børn til så få pædagoger, at der ikke er tid til at skabe relationer eller udvikle det enkelte barn. I folkeskolen når lærerne ud til eleverne på de første to rækker i klassen. Men de mest sårbare og udsatte bagerst i lokalet har de ikke tid til. Vi hører om sygeplejersker, som ikke går, men løber fra stue til stue på afdelingen for at nå rundt til alle de patienter, som har brug for pleje.

Men hvad gør det, hvis bare vi har tilpas engagerede og uegennyttige medarbejdere? Så tåler de nok mosten, fordi den højere mening i arbejdet - at gøre en forskel for udsatte borgere - er deres drive, den såkaldte public service motivation. Eller hvad?

Nej. Det jeg hører fra mine medlemmer er, at de møder stressede ind om morgenen og går endnu mere stressede hjem om eftermiddagen. Og at deres faglighed bliver trådt under fode. De får ikke mulighed for at præstere en god indsats og gøre det, som de oprindeligt er uddannet til. Over tid slår det deres arbejdsglæde og motivation ihjel.

Mange beskriver, at de føler sig som administrative maskiner, der sidder og gør 
det samme dag ud og dag ind, trykker på de samme knapper. Vi har et stigende antal medlemmer, som mistrives i deres arbejde og et stigende antal, som ønsker at blive forhandlet ud af deres job, fordi de må kaste håndklædet i ringen.

\section{Tidlig indsats sparer penge}

Det efterlader os med to store spørgsmål: Hvad kan vi gøre for at vende den udvikling? Og er der nogen i det offentlige landskab, som gør noget andet, der peger i en positiv og bæredygtig retning?

Det sidste først. Vi har heldigvis kommuner, som forstår, at tidlig indsats kan mindske deres udgifter til de mest udsatte børn og familier. Sætter man tidligt ind med solid, faglig indsats, kan man bl.a. forebygge dyre anbringelser af børnene senere i livet. Det betyder, at hver socialrådgiver kan have færre sager og dermed mere tid til at arbejde med at styrke familiens kompetencer og trivsel.

Det lyder enkelt og er det for så vidt også. Kompleksiteten opstår, når ledelsestilsynet kommer ind og konstaterer processuelle fejl i mange af familiesagerne, fordi tidskrav m.m. ikke er overholdt. Og det er de ikke, fordi socialrådgiverne har valgt at bruge tiden og kræfterne på at arbejde med familierne og ikke på at rapportere i systemer. Det er et dilemma. Men den positive side er, at kommunerne har fanget, hvad der skal til.

\section{Hjørring udfordrede styringsdagsordenen}

Vi har også set en kommune som Hjørring, der har sprunget alle rammer. De har kreativt udfordret det gældende styringsregime - med succes. Byrådet besluttede for nogle år siden at investere 125 mio. kr. i beskæfti- gelsesområdet, lægge siloerne ned og tænke ud af boksen. Indsatsen var for de borgere, som var længst væk fra arbejdsmarkedet og $\mathrm{i}$ årevis havde levet af kontanthjælp uden at flytte sig i nogen retning. I løbet af de næste par år lykkedes det at få flyttet omring 1.000 af dem over på anden forsørgelse heraf nogle på førtidspension, fordi de reelt ingen arbejdsevne havde.

Bundlinjen i Hjørring viser i dag en besparelse på 320 mio. kr. om året. Penge, der nu kan kanaliseres over i de områder, som naturligt måtte stå lidt i skyggens venteposition til fordel for indsatsen på jobområdet. Og det bedste for mig er at høre mine medlemmer i Hjørring Kommune fortælle, at de møder glade på arbejde om morgenen og går endnu gladere hjem om eftermiddagen. Interessant er også, at ingen har anfægtet Hjørring Kommune i øvelsen med at udfordre økonomi og styringsinstrumenter.

\section{Budgetloven bremser velfærden}

Hvorfor gør mange flere kommuner så ikke som Hjørring, kunne man spørge? Et af svarene er budgetloven. Kommunerne fattes penge - og har samtidig trecifrede millionbeløb liggende i cigarkassen, som de ikke må bruge til kommunal velfærd. Hvis de måtte det, ville det give bedre velfærd på alle de store områder -beskæftigelse, børn, unge, skole, sundhed og ældre. Derfor bliver det også interessant at se, om en evt. kommende socialdemokratisk regering tør nedlægge den budgetlov, de selv vedtog i 2012 .

Det bringer mig til min afsluttende pointe: Ressourcerne. For uanset hvordan jeg vender og drejer mønten, når jeg frem til samme resultat: Presset på det offentlige arbejdsmarked er resultatet af en ligning, som ikke går op. Forholdet mellem krav og ressourcer er skævt. 


\section{Større tillid og mindre kontrol}

Løsningen, som politikerne, har grebet til, med at effektivisere og styringsregulere i højere og højere grad løser ikke problemet. Her taler bl.a. arbejdsmiljøundersøgelserne jo et tydeligt sprog.

Mine svar hedder derfor: Flere ressourcer, større tillid til og mindre kontrol af de offentligt ansatte. Giv os tid og rum til at udføre vores arbejde fagligt forsvarligt. Lad os få lov at sætte borgeren i centrum, som bl.a. Ledelseskommissionen anbefaler. Lad os forfølge intentionerne i udkastet til hovedloven om sammenhæng $i$ indsatserne og tankerne bag Én plan. Det vil frigive tid og overskud til arbejdet, det vil spare penge og det vil skabe større arbejdsglæde og mindre stress.

I stedet for at afmontere fagligheden hos en lang række dedikerede og dygtige medarbejdere skal vi gå den modsatte vej: Geninstallere den. Genopbygge tilliden i niveauerne på arbejdspladserne, hvor inddragelsen af medarbejderne i væsentlige beslutninger om forandringer og besparelser mange steder er en saga blot, når riget fattes penge og styringsdagsordenen er benhård.

Lad os skabe en positiv spiral, hvor folk ikke bliver syge af at gå på arbejde, men tværtimod går hjem med en oplevelse af, at de har kunnet gøre det, de mødte ind om morgenen for at gøre: En forskel for borgerne.

Mads Bilstrup, formand for Dansk Socialrådgiverforening e-mail:mb@socialraadgiverne.dk 